\title{
THE (TRANS)FORMATIVE POTENTIAL OF THE BIBLE AS RESOURCE FOR CHRISTIAN ETHOS AND ETHICS
}

Elna Mouton

University of Port Elizabeth

Abstract

Many Christians worldwide are currently rediscovering the power of Scripture for their practical lives. The essay argues that the transformative potential of these writings (their continuing authority and relevance in changing times and circumstances) lies in their ability to disclose an alternative moral world, a radically new perspective on reality, a new way of living in the world. Though embedded within patriarchal value systems, the intended rhetorical functions of these documents imply major shifts in the orientation (vision of humanity) and language of their readers. How is this accomplished? With the continual reference to the metaphorical 'world' of the Judaeo-Christian story, they emphasise collective memory as a major recycling strategy toward the development of the faith communities' moral identity and ethos, with healing and wholeness as major substance of their present and future hope. Through liturgy, where the vision of God's presence in the world is formed and nurtured (via the persuasive strategies of identification, alienation and reorientation), Scripture continues to invite contemporary Christian believers to re-imagine and redefine their identity, and (to faithfully choose) to grow toward the full body of Christ - i.e. beyond all limited and stereotypical views of humanity. In a co-operative shared work, Spirit, texts and readers thus engage in a transforming process (Thiselton).

\section{Introduction}

The task of hermeneutical appropriation requires an integrative act of imagination ... (W)henever we appeal to the authority of the (Bible), we are ... placing our community's life imaginatively within the world articulated by the texts.

- (Hays 1990:45-46)

Through the ages Christian believers read, interpreted, preached and appropriated the Bible in a great variety of ways ... with a view - at least until the Enlightenment - to understanding their everyday lives. They were not so much interested in the Bible itself, or in what we today know as the academic, theoretical or intellectual study of the Bible, but in the Bible as canon, as norm - a guiding lamp, a light for their path. Without appropriating the documents of the Bible to their everyday needs and challenges, suffering, fears and hopes, the reading process would for many simply be incomplete and pointless. Calvin's famous metaphor that Christians perceive life, interpret history, nature, the world around them through the glasses of the Bible' aptly describes this process. A pair of glasses is only functional in so far as it helps a person to see through it. Likewise, for most Christians the Bible is only useful in so far as it helps them to live coram Deo. This is its implied rhetorical effect.

Since the Enlightenment, however, the Bible was approached differently, by means of different sets of questions. Paradoxically, people often became more interested in this collection of ancient documents as an object for study - as distinguished and separated from 
understanding life by means of it. The questions being asked of the Bible were increasingly of a scientific, theoretical, 'objective' nature, instead of being personal, existential, and related to the everyday life situations of its readers.

At the moment - broadly speaking since World War I - Christianity is going through a phase during which many believers worldwide are rediscovering the (trans)formative potential of the Bible for their practical lives. I believe that the present cumulative debate regarding the use of the Bible in Christian ethos and ethics needs to be appreciated within this context. ${ }^{1}$ This debate forms part of a much broader discussion amongst literary critics on 'the ethics of interpretation' (cf Fiorenza 1988; Smit 1990a, 1990b, 1991a; Botha 1994a, 1994b), which requires that people take responsibility for their acts of reading - both with regard to the nature of the literature involved and the socio-historical context within which it is being read. An 'ethics of biblical interpretation' is thus concerned with the multidimensional, relational nature of the Bible (representing a wide variety of witnesses of a living relationship between the living God and historical human beings in the everyday reality of their lives - cf Botha 1994a:37-38) and its appropriation in terms of the experiences and needs of contemporary readers/listeners. ${ }^{2}$

Christians who find meaning for their lives through the Bible, explicitly appeal to, or implicitly presuppose the continuing authority of these writings when using them to explain and justify their moral arguments and behaviour. The question is not whether the biblical writings are authoritative for Christians, but how this authority has to be defined, and how its continuing relevance in changing times and circumstances has to be understood. That this is by no means an easy or straightforward issue, speaks from the wide variety of ways in which the Bible has been interpreted and appropriated during the course of history. ${ }^{3}$ The complexity of

1 'For major contributions to this debate see, among others, Ogletree 1983; Verhey 1984; Curran \& McCormick 1984; Birch \& Rasmussen 1989; Fowl \& Jones 1991; Smit 1992, 1994b, 1995; Spohn 1995. For various reasons it is important to distinguish between Christian ethics as a critical, scientific discipline (mainly dealing with processes of decision-making on moral issues), and Christian ethos (morality) as 'the habitual character and disposition of a group ... how people behave themselves, what they think and believe, like and dislike, what they hope and fear, what they regard as shameful or as praiseworthy ... in short, the factors influencing (their) "moral world" (Smit 1991b:52; 1992:303-317; Birch \& Rasmussen 1989:39). Meeks (1993:4) describes the latter as 'a pervasive and, often, only partly conscious set of value-laden dispositions, inclinations, attitudes, and habits'. It is of great significance for the present topic that ethos is the more comprehensive and socially influential factor.

Ethics seldom influences ethos, whereas ethos often determines ethics (Smit 1991b). Hence the particular order in the title of this essay.

2 'To describe the reading process as particularly ethical, basically refers to the wide range of choices readers have to make: What is the Bible? Why were these particular documents selected? What was their intended purpose? Why still read them today? On whose behalf are we reading? What do we expect from them? Do we not (unconsciously) project our own desires, interests and fears onto the texts even before we start reading? (cf Mouton 1995:11-14). '(T)he ethics of interpretation asks (i) who (that is, which individual or group) reads (ii) which Bible (that is, what view of the text does the interpretive community hold, what authrity does it grant the text) (iii) how (that is, using which methods) and (iv) why (that is, whose interests are at stake, what does the interpretive community want to achieve with their acts of interpretation?' (Botha 1994b:4-5). By accounting for the many choices readers of the Bible necessarily make, the 'ethics of biblical interpretation' aims at bridging the methodological gap between theological subdisciplines (since the Enlightenment), and particularly between the often compartmentalised fields of Biblical Studies and Christian Ethics.

3 'Cf Smit 1994a for a very useful typology of historical paradigms in Christian ethics, with the dominant questions being asked during those phases. A major implication of such a historical overview is that the Bible has been used in many different ways in the past with regard to Christian ethos and ethics - depending on the particular question(s) being put to it. This confirms the relational nature of all human knowledge, including our interpretation of the Bible. Some recent trends in Christian ethics include the following variety of accents: a prescriptive approach, an ethics of principles and ideals, 'revealed reality' rather than 'revealed morality', an 
the matter is inter alia due to the dynamic, yet intricate nature of the biblical documents themselves (Lategan 1982), as well as the vast temporal, socio-historical and philosophical differences between the world of the Bible and the world of contemporary readers, which account for the differences between what may be described as biblical and Christian ethos and ethics. ${ }^{4}$ This is confirmed by the hermeneutical approach of some feminist and liberal interpreters who view the Bible as resource for the Christian life with suspicion, because of its intrinsic embeddedness in the patriarchal value system of the Ancient Near Eastern world, and its silence on, for example, slavery as an institution. In the light of the differences between biblical and Christian ethos, the ethics of interpretation holds contemporary readers responsible for their understanding of the authority of Scripture, and particularly for the consistent appropriation of its intended rhetorical effect.

This essay argues for a continuing use of Scripture as a resource for Christian ethos and ethics. Its premise is a view of biblical authority derived from an ethical reading which acknowledges the Bible's dynamic yet complex linguistic, literary, socio- historical and rhetorical nature. In accordance with the Bible's intended moral effect, such a reading has to be legitimised by a corresponding (publicly accountable, trustworthy) way of living (cf Mouton 1995:177-201). Since the fields of Biblical Studies and Christian Ethics sadly have developed each with its own range and focus, it needs to be emphasised how essentially they complement each other. What makes this an urgent moral issue, is not only the integrity and relevance of the Bible which is at stake as resource for Christian ethics as scientific enterprise, but more acutely, its influence on contemporary readers' understanding of God, their identity and public ethos ( $\mathrm{cf}$ n.1)..$^{5}$

Consequently, a primary concern for biblical scholars and Christian ethicists should be: How can the Bible influence and transform the identity awareness and ethos, the language, story and culture of individual people and contemporary society? (Smit 1991b:59- 63, cf 1990a, 1992, 1994b). Mindful that the Bible is read and lived out daily in many, many diverse ways, situations, places and institutions, I shall focus on its potential role in liturgy as major contexts for the formation and nurturing of moral identity and ethos.

ethics of relationality and responsibility, discourse ethics, narrative ethics, and post-modern thinking (Botha 1994a:40-42; Hartin 1994:2-4; Mouton 1995:202-214). The present essay directly links on to the ethics of 'relationality and responsibility'.

4 Christian ethos and ethics (the dynamic and creative reinterpretation of biblical perspectives by subsequent readers, in different socio-historical circumstances) have to be distinguished from biblical ethics or, rather, the implied ethos of each biblical document as understood in its particular context (cf Verhey 1984:159-160,169-197; Gustafson 1984:151-154; Birch \& Rasmussen 1989:11-14; Botha 1994a:36-42). While sharing a basic faith commitment and perspective with those early faith communities, contemporary readers of the Bible are obviously confronted and shaped by different moral issues, stories, historical contexts and forces.

5 'The difference between ethics and ethos often has something to do with the difference between (moral) decisions and acts and (moral) human beings, between acts and agents' (Smit 1991b:52; cf Richardson 1994:89-96), or the difference between an ethics of Doing (Sollen) and an ethics of Being (Sein - cf Birch \& Rasmussen 1989:39-62). For some time Stanley Hauerwas (1981, 1985a, 1985b) and others have argued for a shift in emphasis toward the latter, toward the formation of the moral identity and ethos of a group. His interest is therefore in the formation of 'communities of character', and in the role the Bible can play in it. Hauerwas 'challenges the popular inclination to link ethics with 'difficult decisions' and argues instead for the importance of creating contexts more conducive to deciding one way or another. Contexts like these are found in communities, like the church: social institutions seeking to embody a specific configuration of virtues in its members. These virtues are formed by the language, the 'grammar', the collective stories or narratives of the group ... Much more important, according to Hauerwas, than looking at the role of the Bible in particular difficult decisions and acts, is therefore to look at the role of the Bible within the social institutions where the people's ethos is being formed' (Smit 199lb:53; cf 1994b).

According to this shift, an ethics of responsibility (Doing) presupposes an ethics of relationality (Being). What we do is the result of who we are. 


\section{The Bible and the (trans)formation of moral identity and ethos}

Since my early childhood the Bible intrigued me as a powerful witness to the story of an awesome God who is involved in the everyday lives of people. As such it appealed to me as an invitation to become part of it, to be consoled, inspired, strengthened, challenged, moulded, warned by its vision of a civil world, of God's alternative society, of responsible, moral people, and of good, moral conduct. It certainly had a profound influence on my imagination and language, my life- and world-view, my grasp of reality, of history, of life in general. It became 'the house in which I learned to live' (cf Smit 1991b:59, with reference to Lindbeck). Yet, it was only as a postgraduate student in Biblical Studies that I realised - both with disillusion and relief - that the Bible, in accordance with its dynamic, relational nature, does not provide later readers with a neat, ready-made theological doctrine or ethical system to be followed under all circumstances. The phases of disorientation and reorientation which followed, became a necessary part of a liberating journey back to the same documents, but with a new understanding of their continuing relevance for my life. I discovered that the Bible, instead of being prescriptive to all Christians in exactly the same way, rather resembles the creative processes through which the early faith communities wrestled to understand the will of a living God for their particular times and situations (cf Meeks 1986; 1993:1-17,109-110). Characteristic of these processes of understanding were their continuous orientation and reorientation to the revelation of a living God during the course of history. ${ }^{6}$

For those participants in the Judaeo-Christian story - both in the Hebrew Scriptures (the Christian Old Testament) and the New Testament - the cult, its festivals and specifically its liturgy, provided the space to collectively express and cultivate their vision of, and trust in an omnipotent God. Through rituals of public worship such as sacrifices, hymns, confessions of faith and guilt, prayers, blessings, listening to the covenant stories and the Torah, and later the participation in the sacraments of baptism and eucharist, they were constantly reminded of, empowered and encouraged by who God is and by what God had done in the past. By retelling and reactualising their stories from within the covenant relation, their identity and corresponding ethos as a community of faith would be shaped and constituted (cf Dt 7:6-11; Eph 2:11-22). ${ }^{7}$ Collective memory thus played a crucial role in the formation of their self-

6 Confessions about God in both the Old and New Testaments reflect a great diversity in religious experience, language, style, genre and socio-historical circumstances. Hence the variety of names and metaphors used for God to express and explain those experiences. As a very cursory observation, one might say that the patriarchs experienced God as a personal, omnipresent, nearby reality. During the time of the exodus this God was acknowledged as the gracious Redeemer who liberated his people from slavery and bondage, while the sojourners in the wilderness and at Sinai described him as a living God who inter alia spoke through symbols of fire and water. During the period of the northern Kingdom He was confessed as the holy One who does not share his people's loyalty with anyone or anything else. During the period of the southern Kingdom metaphors for God focus on him as the righteous and just King who rules from within the temple, protecting his people and caring for them. In exilic times He became known as a trustworthy Creator being able of making something new amid chaos and disaster, and in post-exilic times as the exalted One, though still being with his people. It is the memory of these events, these images of God, celebrated and enacted during Israel's festivals, which essentially shaped their identity as the people of Yhwh, and which determined how they were to respond in their practical everyday living. These confessions and memories are surprisingly reinterpreted and fulfilled in the life and ministry of Jesus of Nazareth, the focus and authority of the New Testament writings. For contemporary Christian communities of various traditions, these memories represent the irreplacable beginning of the never-ending story of a living God who continues to reveal Godself in relation to faith-ful human beings (cf Birch \& Rasmussen 1989:17-34,120-133; Mouton 1995:189-201).

7 The stories of the biblical communities witness to the reality that they did not so much have a social ethic as that they were a social ethic, a koinonia ethic in the process of formation. 'The community's task was to socialize its 
understanding - not only the memory of good times of victory and success, but also the deliberate recalling and uncovering of past sins, failures and negligence. Through repentance and reconciliation, remembering would become a hopeful act, a confession of faith in the living God of history, which would open up new perspectives on the present and future. ${ }^{8}$ Closely related to cultic practices, the process of moral formation would find its focus in the context of family life (cf Dt 6:6- 25; Eph 5:21-6:9 and other domestic codes in the NT).

Similarly, the biblical documents have stimulated and facilitated an ongoing process of interpretation (cf Verhey 1984:179-187). The imperative of such an ongoing process is in fact implied in the very nature of these texts (Lategan 1982:48-50; Fowl \& Jones 1991:36-44). An ethical reading of the Bible by subsequent readers therefore calls for a continuous wrestling, for imaginative, Spirit filled, critical and faithful reflection on the active presence and will of God in ever changing times and circumstances. It is in this sense that biblical scholars and Christian ethicists share the moral obligation to engage in the creative tension between the dynamics of the biblical texts and the 'worlds' of present day readers (Fiorenza 1988:13) between history and eschatology, between the 'already' and the 'not yet', between remembrance and hope. It is the creativity of such 'in between' stages that provided the biblical authors with the stimulus, values and virtues to redefine their humanity and moral existence in different times and places, under many diverse circumstances.

The experience of God on the threshold between memory and hope is epitomised in the public ministry, sacrificial death, resurrection and ascension of Jesus Christ (cf Eph 2:1-22; Col 2:14-15). The Christ event - the underlying theme of the New Testament documents would indeed challenge and exceed all previous experiences and interpretations of the God of the Hebrew Scriptures (cf Mk 8:27-9:1). The identity and ethos of the Jesus followers and early Christian communities would now be determined by their reorientation to the alien, completely other, yet for them truthful story of Jesus Christ. This story is particularly characterised by the sociologically shameful symbol of a cross (cf Olyan 1996:214 n.43), which is reinterpreted and becomes an honourable symbol for those who adhere to Christ by faith (Meeks 1993:14-15,131-135). The dramatic consequences of his death and exaltation for both Jews and Gentiles are described in transitional terms: Those who were dead, have been made alive, those who were far away, excluded from citizenship in Israel, have been brought near, and those who formerly had been power- and statusless foreigners and aliens, have been made fellow citizens with God's people and members of his household (Eph 2). In this way

members into forms of life which displayed the kind of conduct befitting the experience of God in community. To be a Jew was to learn the story of Israel and the rabbinic traditions well enough to experience the world from within these stories, and to act in accord with that experience as a member of an ongoing faith community. Similarly, to be a Christian was to learn the story of Israel and of Jesus and the ongoing church traditions well enough to experience the world from within those stories, and to act in keeping with that experience, as a member of that community' (Birch \& Rasmussen 1989:21, cf 66-84; Hauerwas 1985a:181-184; Meeks 1993:172$173,189-210$ ). A primary function of liturgy and ritual, therefore, is to commemorate and nurture this communal identity and corresponding ethos in covenant relation with a living God (cf Olyan 1996).

8 In these contexts the typical Jewish prayer form, the berakah, fulfilled an important role. It comprised two elements: a doxological exclamation or appeal to praise God, followed by the reasons why God had to be praised (cf Gen 14:20; 24:27; Pss 66:20; 103-106; 111; 117-118; 124:6; 135-136; 138; 144-145; 148- 150).

Fundamentally the berakah was an act of remembrance where God was to be praised for the way He had worked in the past. By remembering his deeds, his people were moved again to praise him (Johnson 1986:58-59). This prayer form also occurs in the New Testament (cf 2 Cor 1:3-11; Eph 1:3-14; 1 Pt 1:3-12). As an act of remembering it simultaneously becomes an act of dismembering , because of the way in which previous (often absolutised) traditions such as election, covenant, law and the temple with its dividing wall had to be reinterpreted in the light of the Christ event. 
Christ gave birth to a new creation, a new humanity with a new identity and corresponding ethos.

In general, one may say that the intended moral effect of the biblical documents is a radical and total revisioning of the lives of their readers from a theocentric perspective, from within the relationship with a living God. ${ }^{9}$ It is exactly in the dynamic process of such a continuous reorientation that I believe the transformative potential of the ancient canonised texts of the Bible lie for laters readers. How would such a process work?

\section{The rhetorical and referential power of the Bible}

With regard to the rhetorical and transformative aspects of the biblical documents, I shall focus on the (re)orientating potential of the categories of metaphor and story. ${ }^{10}$ In this context our interest in metaphor and story particularly lies in their referential and relational nature (cf Lategan 1985, 1994, 1996:223-229; Van Huyssteen 1987). Lategan (1994:134) rightly claims that a 'better understanding of the function of reference in all its forms holds the key to unlock the transformative potential of (biblical) texts in contemporary situations'. According to Ricoeur (1975; 1976:89-95; 1977:216-256; cf Thiselton 1992:351-372; Lategan 1992:154; 1994:131-133), the referential or transformative power of a text lies in its ability to suggest, to open up, to facilitate, to mediate, to make possible, to produce a 'world in front of it', a 'proposed world' which readers may adopt or inhabit, an alternative point of view with which they can identify. In this way a text discloses a possible new way of looking at things.

Since the development of reader response and reception theories, Iser's concept of the 'implied reader' became a powerful tool in describing the role of readers or audiences in the process of understanding. The implied or textually defined reader refers to 'the anticipated role a potential reader is expected to play in order to actualize the text ... (It) is a device to engage the real reader by offering a role to be played or an attitude to be assumed' (Lategan 1989:5,10). In this sense metaphor, tradition (as extended metaphor) and parable (story) are important lenses, clues, signals or shifting devices by means of which an author can instruct or guide his/her audience toward adopting a preferred position, or inhabiting a new moral world. In helping them to see differently, these lenses may help readers to integrate and redescribe their experiences - in so far as they are willing to accept their alternative perspectives. As acts of remembrance and dismembrance, metaphor and story then become crucial instruments for moral formation.

Metaphors and stories function on two important levels. Firstly, they are used to identify different dispensations, and preferred or non-preferred positions, attitudes and actions. Secondly, they are used as rhetorical strategies 'to effect the shifting of position' (Lategan 1993:402). Indicating preferred and non-preferred positions is one thing. To achieve a shift in

9 Gustafson's major work on ethics, his two-volumed Ethics from a Theocentric Perspective (1981, 1984. Chicago: University of Chicago Press) emphasises that the essence of, and prerequisite for Christian ethics is the perspective of faith in a sovereign God. He argues for a relationality and responsibility model as the primary way to understand Christian ethics. This approach focuses on the Christian's response to what God has done in history and is still doing today. It places God in the very centre of moral activity. Gustafson's approach is closely related to the views of Richard H Niebuhr (1941) who emphasises the Christian's responsibility to listen carefully, to be open and responsive to the work of a living God (cf Botha 1994a:41-42; Mouton 1995:222-234; Stassen 1996).

10 In the metaphorical theology of Sallie McFague (1982) 'metaphor' and 'parable' (a particular type of story) function as a central notion for the understanding of Christian ethics and the formation of moral people - in a way similar to the functioning of 'story' in the narrative ethics of Hauerwas. Accordingly, these notions have the potential to impact on biblical readers by continuously reorienting, redefining and transforming their selfunderstanding and ethos as disciples of Jesus Christ. 
the right direction is, however, quite another matter. How do the biblical authors go about ensuring the desired result? How do they influence their readers to accept their new position and lifestyle coram Deo? How is their change of attitude and behaviour supposed to take place?

For the biblical authors the key to change and moral formation is provided by the interrelated communication processes of orientation, disorientation, and reorientation (Ricoeur 1975:122-128; 1976:46-53; 1977:65-100; McFague 1982:46-48), or association and disassociation (Lategan 1993:402). These processes essentially reveal the (re)orientating or transformative potential of metaphorical language, which forms the heart of biblical hermeneutics. ${ }^{11}$ I briefly illustrate this by showing how the memory of Jesus functions metaphorically in liturgy.

With reference to McFague (1982:31-66,90-194), Christ's role in the New Testament documents and in ongoing moral formation may be described as that of an extended 'metaphor or parable for God' and a 'model for Christian behaviour..'2 These notions provide important insight into the processes through which the Christian story may impact on biblical readers by continuously reorienting and transforming their self-understanding and ethos as disciples of Jesus Christ:

If we say ... that Jesus of Nazareth is par excellence the metaphor of God, we mean that his familiar, mundane story is the way, the indirect but necessary way, from here to there ... Metaphoric meaning is a process, not a momentary, static insight: it operates like a story, moving from here to there, from 'what is' to 'what might be' (McFague, quoted by Spohn 1984:100).

Like metaphors, the essence of parable is that it works through the ordinary, mundane, and secular - by indirection - to bring about new insight. This means that we start with the (more familiar) work of Jesus from 'below', and move indirectly to his person, and to the invisible (unfamiliar) God whom He represents. The whole network of Jesus' life - his words and deeds - thus provides a grid or screen through which the understanding of God can be realigned (cf McFague 1982:49-54; Hays 1990:45-50).

How, then, does Jesus' designation as parable of God realign, redefine or reorientate (Ricoeur 1975:122-128; 1976:89-95; 1977:216- 256) people's understanding of God? As a true and novel metaphor, Jesus as parable always reorders, shocks and upsets familiar, conventional preconceptions and understandings of God. In this sense liturgy should always

11 Biblical metaphors inter alia serve as windows (albeit hazy) through which the processes of identification, estrangement and reorientation, typical of the image-making capacity of the human mind can be viewed. Any creative act of interpretation, discovery, decision-making, transition or transformation can be recognised as the Imaginative combination and synthesis of the familiar into new wholes (McFague 1982:35-36), which is a redescription of reality (Ricoeur 1975:122-128; 1976:45-69).

12 McFague (1982:31-54) argues that the basic characteristics of metaphorical language (indirection, extravagance, mundanity) also apply to Jesus as parable. In general, we can say that parables function in the play of two different orientations to reality. Throughout the parables these perspectives are in permanent tension with each other, and the effect of their interaction is profound disorientation (cf Ricoeur 1975:122-128). Drawing on Ricoeur, McFague (1982:46-47) suggests that parables work on a pattern of orientation, disorientation, and reorientation: 'A parable begins in the ordinary world with its conventional standards and expectations, but in the course of the story a radically different perspective is introduced that disorients the listener, and finally, through the interaction of the two competing viewpoints, tension is created that results in a redescription of life in the world'. Parables were thus meant to reverse the expectations of their listeners and readers, and to shift their moral vision and behaviour in radical ways (cf Lategan 1992:154). 
distance its participants from the obvious values and virtues of their everyday life, by offering them an alternative lifestyle. In McFague's view the heart of the drama of Jesus' life and death is the tension that it manifests between accepted ways of relating to God and others, and a new way of living in the world. As such Jesus' life and especially his death and resurrection has to be viewed as radical and iconoclastic, continuously calling into question the comfortable and secure homes that our interpretations of God have built for us (cf McFague 1982:51-54). Like Christ we are called to a life in but not of the world, to lives that always stand in criticism of the status quo and that press toward fulfillment of the body of Christ. This means that specific virtues and values associated with him (such as love, compassion, humility, holiness, righteousness, joy, peace, hope) are generated toward those who identify with him. Christians (choose to) love and forgive one another, because they have been loved and forgiven a thousand times over. They accept, with loving compassion, people different from themselves, foreigners, strangers, outsiders, people excluded by social biases, and care for them. Through various strategies the New Testament authors encourage their readers to think of themselves in terms of the new position they ought to assume - as disciples of Jesus, as fellow-citizens with God's people, as one body in Christ, as a new humanity. By inviting humankind to assume its honourable status in Christ, these documents offer their readers a new selfunderstanding, leading to a new ethos, new attitudes and actions.

In general the New Testament notion of moral identity and ethos functions in the play of two different orientations, modes of existence or perspectives on reality - in Christ and outside Christ. To summarise, one may say that the starting point of all persuasive strategies is the delicate tension between identification, alienation and reorientation. For later readers these processes hold the key to the transformative potential of the biblical documents. To inhabit their strange, alternative world is a gift of God's grace (Eph 2:5,8-10) and a faith-ful hermeneutical choice:

In a co-operative shared work, the Spirit, the text, and the reader engage in a transforming process, which enlarges horizons and creates new horizons (Thiselton 1992:619; cf Is 1:1820; Mt 11:28-30; Jh 14:26, 16:13).

\section{Re-imagining the encounter between Scripture and contemporary readers}

We have seen that the biblical documents are characterised by the dynamic process of the early faith communities' search to understand human existence in the light of the revelation of a living God. It has also been argued that the transformative potential of the Bible lies in its referential power, in its ability to point beyond itself to a reality which it could only describe in a limited and provisional manner: the full story of a living God's engagement with creation. The question regarding its ongoing authority for later readers may now be phrased as follows: How can the (culturally-bound) alternative world of the Bible be brought into relation with, and impact on present-day moral challenges $?^{13}$ In accordance with its relational nature, the authority and transformative power of the Bible for subsequent readers first of all resides in the

13 Phrased in terms of the three major sets of ethical questions which emerged through the history of (Christian) ethics (Smit 1994a:20-21), one may firstly ask: What is the biblical, the Christian view of a moral, healthy and happy society? Secondly: What is the Christian view of responsible, moral decisions, actions, conduct - under specific circumstances? And thirdly: What constitutes the biblical, the Christian view of good and moral people? What is their character to be like, and where are such people formed? (cf Birch \& Rasmussen 1989:40-58; Mouton 1995:201-241). By focusing on the moral (trans)formation of people and an ethics of Being (cf $\mathrm{n} .5$ ), this essay presumes that Christians who truthfully are what they claim to be, will also take society and moral decisions and conduct seriously - as an expression of their primary identity in Christ. 
continuing encounter with the God mediated and stimulated by these texts (cf Lategan 1992:154; 1994:131-133; Mouton 1995:192-194).

To respond faithfully and with sensitivity to the rhetorical functions of the Bible, is to account for its transformative potential amid its cultural-historical biases, that is the typically human process of redescription in the light of new knowledge and experience underlying it. Involvement in the creative space between the biblical texts and contemporary contexts therefore asks for an open-endedness which humbly recognises the provisional nature of all faith utterances. In order to allow for explanations and experiences of a living God who is constantly revealed in new and surprising ways (cf Meeks 1993:217-219), later readers are challenged inter alia to account for its patriarchal language, and to create the inclusive language needed to express and construct their experiences. ${ }^{14}$ These documents do not bind us in a rigid, legalistic way, but liberates us towards the imaginative appropriation of the mighty, healing power of God's love in new circumstances. In spite of their patriarchal embeddedness, these documents invite us to identify with Christ in the paradoxical triumph of his death, resurrection and exaltation, and to grow beyond all limited and stereotypical views of humanity. In terms of Taylor's 'postmodern trilemma' (1990:40-45), they challenge us to focus on a vision which respects (and where necessary creatively reinterprets) tradition, celebrates plurality, and resists any form of domination... Therefore, to respect the Bible's transformative potential, is to dedicate oneself to accomplishing the full potential of the body of Christ. ${ }^{15}$ Anything less would confine the God of the Bible to the boundaries of ancient canonised texts

14 In this sense I agree with Sandra M Schneiders' objection (referred to by Spohn 1995:75) to Fiorenza'a proposal that the offensive portions of the canon (from the perspective of contemporary readers) be denied revelatory status. Schneiders convincingly shows how the the continuing interaction between the foundational text of a community and those who continue to interpret it over time can free the text from the limitations of its original authors. To this Spohn (1995:75) adds: 'If we discount the authority of Scripture because of its authors' biases or the subsequent uses to which it has been put, we might be rejecting the very resource which can transform the present'.

15 This vision of a moral society implicitly results from a Christian community which truthfully lives up to its calling within a particular socio-historical context (cf Fowl \& Jones 1991:44-50; Richardson 1994:96-100). In a discussion of the relation between 'the two stories' of Christianity and society, and with reference to Niebuhr's Christ and Culture, Müller and Smit (1994:389) describe this ongoing hermeneutical process as follows: 'In terms of the story-approach, the institutionalised church, as 'a story-telling and -celebrating community' ... always exists within the more comprehensive community of a particular society, with its own collective stories and histories, celebrations and hopes, institutions and social practices'. And, in terms of the very fragile metaphorical network involved in such a process, they add: 'The church tells its own story in ways between the extremes of becoming merely a repetition of the public stories already at hand, or of being so radically different from the public stories that no meaningful connection is possible' (cf Lategan 1992:627; 1994:131-133).

In concurrence with the basic perspectives of the New Testament documents, Müller and Smit (1994:399406) further argue that the basic identity and character of the church ought to be visible when sharing its story in public worship (as a liturgical act). That means that the church has the obligation to proclaim, celebrate and live the one, strange, full, and true story of God the Father of Jesus Christ, of Christ as parable of God's radical and unconditional grace and care for sinners, strangers and sufferers, and the life-giving and life-enabling Spirit of Christ; and to wrestle with its implications for a needy society. In South Africa in particular there is an urgent need for the Christian church 'to be the place where other voices, including those from the bottom and the edges. and especially those from the marginalised and the victims, the voiceless and the downtrodden, should be heard' (Müller \& Smit 1994:401). The thrust of the New Testament documents is an invitation to the rich diversity of society, races, sexes, classes and cultures - all to be included in the one church, under the fullness of the lordship of Christ (cf Ogletree 1983:152-168; Eph 1:10). At the same time the church is characterised by its holiness, by its strange, alien, paradoxical story, 'witnessing to ... the Completely Other, the Holy One ... Telling and celebrating the Christian story means listening to a 'different' story, a story of challenge and calling, of conversion and change' (Müller \& Smit 1994:403). 
in a way contradictory to their own nature, and can therefore not be considered as normative.

At the moment the South African society is undergoing a very rapid transition from what may broadly be described as a (homogeneous) premodern to a (pluralistic) modern and even postmodern phase (Smit 1994a:20-21). The evil spirit of 'apartheid' (as sexism, racism, classism, traditionalism, etc), a 'dividing wall of hostility' (Eph 2:14), has deeply distorted the sense of humanity, the identity and ethos of all people. No-one is unaffected by it, even those who do not realise it: the poor and the rich, women and men, black and white. We all carry personal scars and the scars of our country's history.

For such a deeply broken situation to be cured, asks for nothing less than a miracle. The Christian churches in South Africa, as well as Biblical Studies and Christian Ethics as part of a broader religious education programme, face an enormous challenge to reclaim the transformative potential of the biblical writings as an invitation to accomplish a healed and full body of Christ. ${ }^{16}$ It invites Christians to discuss ethics in communion (Fowl \& Jones 1991:110134), and to first of all develop what Richard Niebuhr (1941:84-86) calls 'a common memory':

When men (sic) enter into a new community they not only share the present life of their new companions but also adopt as their own the past history of their fellows ... Where common memory is lacking, where men (sic) do not share in the same past there can be no real community, and where community is to be formed common memory must be created (italics EM).

This means that Christians - people sharing the biblical perspective of reconciliation - have to listen to the stories of all the people in South Africa, particularly those who have not been considered as important in the past, and to adopt the past (sins) of other groups as our own, and to risk to forgive them and ourselves for what we have done to each other. This will allow us the opportunity to lament the loss of our full humanity for such a long time, and to grow from remembering our inherited traditions of alienation to dismembering them in the light of Christ's healing love. The documents of the New Testament witness to Christ's power to translate different stories into one new story (cf Eph 1:10), into a new common memory, which might become a common hope for the future. Hopefully the present moment will become a kairos, a rebirth, a resurrection in terms of rethinking, re-imagining and redefining our humanity. ${ }^{17}$ Hopefully it will free us to respond truthfully to the presence of the living God, and to act now.

An ethical reading of the Bible today does not allow for final, unalterable answers, decisions and certainties. It rather encourages and challenges us to live patiently and humbly with the tension of risk, paradox, pain, and even ridicule. Appropriating the alternative vision of these writings in terms of the formation of moral people, the transformation of a moral society, and the information of moral action, is a slow, lifelong, more often than not

16 Bearing in mind the often negative role the Bible has played in the history of SA, especially in terms fo the legitimisation of racism and sexism (cf Smit 1991b), 'transformative potential' here refers to the search for a communal justice - not in an absolutistic way that of a particular interest group, necessary though it may be under given circumstances. In the context of this essay 'transformative potential' is therefore to be regarded as postfeministic and post-liberalistic.

17 In concurrence with Ackermann's relational anthropology (1991:100-103; 1992:16-23) and feminist theology as liberating praxis (1994:201-208), the key words in my proposal are 'relationality' and 'risk'. 'Relationality as basis for a transformative view of humanity is ... concerned with our relationships with ourselves, with one another, with God and with our environment' (Ackermann 1991:102). It is the opposite of alienation, apathy and exclusion. 'Risk' refers to the courage, energy and commitment required to deal with the deeply entrenched power of patriarchy and other forms of oppression (cf Ackermann 1994:207). Christ is our model with regard to this stereoscopic vision of transformation. 
cumbersome process. There is no instant way toward accomplishing it. It is a narrow road which calls for a hermeneutic of trust, hope and commitment.

In the final analysis the key to the transformative potential of the Bible as a continuing resource for Christian ethos and ethics is a moral choice. 'We are what we repeatedly do', Aristotle once said. 'Excellence then, is not an act, but a habit'. Phrased in terms of the intended rhetorical effect of the biblical writings: As Christians we are what we repeatedly choose to be. We see according to the 'glasses we wear'. And how we live is the result of what we see, of who we are.

\section{BIBLIOGRAPHY}

Ackermann, D 1991. Being Woman, Being Human, in Ackermann, D, Draper, JA \& Mashinini, E (eds) 1991. Women Hold up Half the Sky: Women in the Church in Southern Africa, 93-105. Pietermaritzburg: Cluster Publications.

Ackermann, D 1992. Defining Our Humanity: Thoughts on a Feminist Anthropology. JTSA 79. 13-23.

Ackermann, D 1994. Faith and Feminism: Women Doing Theology, in De Gruchy, J \& Villa-Vicencio, C (eds), Doing Theology in Context: South African Perspectives, 197-211. Maryknoll: Orbis.

Birch, BC \& Rasmussen, LL 1989. Bible and Ethics in the Christian life. Minneapolis: Augsburg.

Botha, J 1994a. The Bible and Ethics, in Villa-Vicencio, C \& De Gruchy, JW (eds), 36-45.

Botha, J 1994b. Subject to Whose Authority? Multiple Readings of Romans 13. Atlanta: Scholars Press.

Curran, CE \& McCormick, RA (eds) 1984. The Use of Scripture in Moral Theology. New York: Paulist Press.

Fiorenza, ES 1988. The ethics of Biblical interpretation: Decentering Biblical Scholarship. JBL 107/1, 3-17.

Fowl, SE \& Jones, LG 1991. Reading in Communion: Scripture and Ethics in Christian Life. London: SPCK.

Gustafson, JM 1984. The Place of Scripture in Christian Ethics: A Methodological Study, in Curran, CE \& McCormick, RA (eds), 151- 177.

Hartin, PJ 1991. Methodological principles in interpreting the relevance of the New Testament for a new South Africa. Scriptura, 1-16.

Hauerwas, S 1981. A Community of Character: Toward a Constructive Social Ethic. Notre Dame: University of Notre Dame.

Hauerwas, S 1985a. The gesture of a truthful story. Theology Today 42/2, 181-189.

Hauerwas, S 1985b. Character and the Christian Life: A Study in Theological Ethics. San Antonio: Trinity University. 
Hays, RB 1990. Scripture-Shaped Community: The Problem of Method in New Testament Ethics. Interpretation XLIV/1, 42-55.

Johnson, LT 1986. The writings of the New Testament: An Interpretation. Philadelphia: Fortress.

Lategan, BC 1982. Inleiding tot de Uitlegging van het Nieuwe Testament, in Klijn, AFJ (red), Inleiding tot de studie van het Nieuwe Testament, 47-70. Kampen: JH Kok.

Lategan, BC 1985. Reference: Reception, Redescription and Reality, in Lategan, BC \& Vorster, WS, Text and Reality: Aspects of Reference in Biblical Texts, 67-93. Philadelphia: Fortress.

Lategan, BC 1989. Introduction: Coming to Grips with the reader. Semeia 48, 3-17.

Lategan, BC 1992. Hermeneutics, in Freedman, DN (ed-in-chief) 1992, The Anchor Bible Dictionary Vol 3, 149-154. New York: Doubleday.

Lategan, B 1993. Textual Space as Rhetorical Device, in Porter, SE \& Olbricht, TH (eds), Rhetoric and the New Testament: Essays from the 1992 Heidelberg Conference, 397-408. Sheffield: JSOT.

Lategan, BC 1994. Revisiting Text and Reality. Neotestamentica 28/3, 121-135.

Lategan, B 1996. Imagination and Transformation: Ricoeur and the Role of Imagination. Scriptura 58, 213-232.

McFague, S 1982. Metaphorical Theology: Models of God in religious language. London: Fortress.

Meeks, WA 1986. The moral world of the first Christians. Philadelphia: Westminster.

Meeks, WA 1993. The Origins of Christian Morality: The First Two Centuries. New Haven: Yale University.

Mouton, AEJ 1995. Reading a New Testament document ethically: Toward an accountable use of Scripture in Christian ethics, through analysing the transformative potential of the Ephesians epistle. DTh thesis, University of the Western Cape.

Mouton, J \& Lategan, B (eds) 1994. The relevance of theology for the 1990s. Pretoria: HSRC.

Müller, BA \& Smit, DJ 1994. Public worship: A tale of two stories, in Mouton, J \& Lategan, B (eds), 385-408.

Niebuhr, HR 1941. The meaning of revelation. New York: MacMillan Publishing Co.

Olyan, SM 1996. Honor, Shame, and Covenant Relations in Ancient Israel and its Environment. JBL 115/2, 201-218.

Ogletree, TW 1983. The use of the Bible in Christian ethics. Philadelphia: Fortress.

Richardson, N 1994. Ethics of Character and Community, in Villa-Vicencio, C \& De Gruchy, JW (eds), 89-101.

Ricoeur, P 1975. Biblical Hermeneutics. Semeia 4, 29-148.

Ricoeur, P 1976. Interpretation Theory: Discourse and the Surplus of Meaning. Fort Worth: Texas Christian University.

Ricoeur, P 1977. The Rule of Metaphor: Multi-disciplinary studies of the creation of meaning in language, tr by $\mathrm{R}$ Czerny, $\mathrm{K}$ McLaughlin \& $\mathrm{J}$ Costello. Toronto: University of Toronto.

Smit, DJ 1990a. The ethics of interpretation - new voices from the USA. Scriptura 33, 1628.

Smit, DJ 1990b. The ethics of interpretation - and South Africa. Scriptura 33, 29-43. 
Smit, DJ 1991a. Wat beteken 'die Bybel sê'? 'n Tipologie van leserkonstrukte. HTS 47/1, 167-185.

Smit, DJ 1991b. The Bible and ethos in a New South Africa. Scriptura 37, 51-67.

Smit, DJ 1992. Oor 'Nuwe-Testamentiese etiek', die Christelike lewe en Suid-Afrika vandag, in Breytenbach, C \& Lategan, B (reds), Geloof en Opdrag: Perspektiewe op die etiek van die Nuwe Testament. Scriptura S9a, 303-325.

Smit, DJ 1994a. Morality and Individual Responsibility. JTSA 89, 19-30.

Smit, DJ 1994b. A story of contextual hermeneutics and the integrity of New Testament interpretation in South Africa. Neotestamentica 28/2, 265-289.

Smit, DJ 1995. Saints, disciples, friends? Recent South African perspectives on Christian ethics and the New Testament. Paper read at SBL international meeting, Budapest, 23-26 July 1995.

Spohn, WC [1984] 1995. What Are They Saying About Scripture and Ethics? Fully revised and expanded ed. New York: Paulist Press.

Stassen, GH 1996. A New Vision, in Stassen, GH, Yeager, DM \& Yoder, JH, Authentic Transformation: A New Vision of Christ and Culture, 191-268. Nashville: Abingdon.

Taylor, MK 1990. Remembering Esperanza - A Cultural-Political Theology for North American Praxis. New York: Orbis.

Thiselton, AC 1992. New Horizons in Hermeneutics: The Theory and Practice of Transforming Biblical Reading. Grand Rapids: Zondervan Publishing House.

Van Huyssteen, $\mathrm{W}$ 1987. The realism of the text: A perspective on biblical authority. Pretoria: UNISA.

Verhey, A 1984. The Great Reversal: Ethics and the New Testament. Grand Rapids: Wm B Eerdmans.

Villa-Vicencio, C \& De Gruchy, J (eds) 1994. Doing Ethics in Context: South African Perspectives. Cape Town: David Philip. 